\title{
DNA Footprints: Using Parasites to Detect Elusive Animals, Proof of Principle in Hedgehogs
}

\author{
Simon Allen ${ }^{1,2, *}{ }^{\mathbb{D}}$, Carolyn Greig ${ }^{3}$, Ben Rowson ${ }^{4}\left(\mathbb{D}\right.$, Robin B. Gasser ${ }^{5}$, Abdul Jabbar ${ }^{5}(\mathbb{D}$, \\ Simone Morelli ${ }^{6}{ }^{\circ}$, Eric R. Morgan ${ }^{2,7}$, Martyn Wood $^{1}$ and Dan Forman ${ }^{3}$ \\ 1 Gower Bird Hospital, Sandy Lane, Parkmill, Gower, Swansea SA3 2EW, UK; \\ martyn@gowerbirdhospital.org.uk \\ 2 School of Biological Sciences, University of Bristol, Bristol Life Sciences Building, 24, Tyndall Avenue, \\ Bristol BS8 1TQ, UK; eric.morgan@qub.ac.uk \\ 3 College of Science, Swansea University, Singleton Park, Swansea, Wales SA2 8PP, UK; \\ c.greig@swansea.ac.uk (C.G.); d.w.forman@swansea.ac.uk (D.F.) \\ 4 Department of Natural Sciences, National Museum of Wales, Cardiff, Wales CF10 3NP, UK; \\ ben.rowson@museumwales.ac.uk \\ 5 Faculty of Veterinary and Agricultural Sciences, The University of Melbourne, Parkville 3010, Australia; \\ robinbg@unimelb.edu.au (R.B.G.); jabbara@unimelb.edu.au (A.J.) \\ 6 Faculty of Veterinary Medicine, Teaching Veterinary Hospital, University of Teramo, 64100 Teramo, Italy; \\ smorelli@unite.it \\ 7 School of Biological Sciences, Queen's University Belfast, 19 Chlorine Gardens, Belfast BT9 5DL, \\ Northern Ireland, UK \\ * Correspondence: simon@gowerbirdhospital.org.uk; Tel.: +44-179-237-1630
}

Received: 30 April 2020; Accepted: 12 August 2020; Published: 14 August 2020

Simple Summary: Nocturnal and elusive animals are notoriously difficult to count-hedgehogs being a prime example. Therefore, any reliable way to demonstrate the presence of a particular animal, within a given area, would be a valuable addition to many ecologists' tool kits. The proposed method is based upon the idea that you can find a parasite, specific to a vertebrate animal of interest that has a life stage within an invertebrate host. Molecular detection of these parasites is then carried out in the more abundant and easily collected invertebrate intermediate host. The key to this proposed method is the specificity of the parasite to the vertebrate animal and its detection in the invertebrate intermediate hosts. Crenosoma striatum is specific to hedgehogs and was chosen as the parasite to develop the molecular survey tool for hedgehogs, an elusive nocturnal species of considerable interest at present. Results revealed the presence of the nematode only at a site known to be inhabited by hedgehogs confirming the potential of this method to improve the accuracy of recording hedgehog populations.

Abstract: The Western European Hedgehog (Erinaceous europaeus) is a nocturnal animal that is in decline in much of Europe, but the monitoring of this species is subjective, prone to error, and an inadequate basis for estimating population trends. Here, we report the use of Crenosoma striatum, a parasitic nematode specific to hedgehogs as definitive hosts, to detect hedgehog presence in the natural environment. This is achieved through collecting and sampling the parasites within their intermediate hosts, gastropoda, a group much simpler to locate and sample in both urban and rural habitats. C. striatum and Crenosoma vulpis were collected post-mortem from the lungs of hedgehogs and foxes, respectively. Slugs were collected in two sessions, during spring and autumn, from Skomer Island ( $n=21)$, which is known to be free of hedgehogs (and foxes); and Pennard, Swansea $(n=42)$, known to have a healthy hedgehog population. The second internal transcribed spacer of parasite ribosomal DNA was used to develop a highly specific, novel, PCR based multiplex assay. Crenosoma striatum was found only at the site known to be inhabited by hedgehogs, at an average prevalence in gastropods of $10 \%$ in spring and autumn. The molecular test was highly specific: One mollusc 
was positive for both C. striatum and C. vulpis, and differentiation between the two nematode species was clear. This study demonstrates proof of principle for using detection of specific parasite DNA in easily sampled intermediate hosts to confirm the presence of an elusive nocturnal definitive host species. The approach has great potential as an adaptable, objective tool to supplement and support existing ecological survey methods.

Keywords: Hedgehog; PCR; Crenosoma striatum; rDNA; Gastropod; Nematode; Biological tag

\section{Introduction}

Objective methods for monitoring wild animals are needed to support management efforts, but are rarely straightforward, especially for elusive and nocturnal species. A complete census is usually impossible, and surveys more often rely on observations of individuals and indirect evidence of their presence, such as faecal counts or tracks [1]. With regards to elusive nocturnal animals specifically, even detection can be difficult, as exemplified by carnivore species that are widely dispersed, solitary and nocturnal [1-3]. Locating even the largest of terrestrial mammals, for example, the African forest elephant, can be a difficult task fraught with contestable results [4].

Western European Hedgehogs (Erinaceus europaeus Linnaeus, 1758) are classified as a species of least concern [5]; however, there is strong evidence of a recent decline in numbers across mainland Europe and in the UK [6-10]. Estimates suggest a reduction in UK populations within the range of $5-7 \%$ in the last 50 years [11], with one study suggesting a potential $25 \%$ reduction over the last decade [12]. Current survey methods rely on physical sightings and subjective evidence, such as scats (faecal deposits), tracks and carcases from road deaths, to determine the presence of hedgehogs [13-16]. Given the difficulties in sighting and correctly monitoring nocturnal animals, such as hedgehogs, there is a need to develop a wider panel of objective, evidence-based survey methods to supplement and confirm the findings of those currently used [17].

The use of parasites to monitor host populations has long been employed in the aquatic environment for fish populations [18-21], and more recently to quantify the presence of the elusive diamondback terrapin [22]. The use of parasites and their DNA as biological markers, however, remains underdeveloped in terrestrial environments. The parasitic nematode Crenosoma striatum is a lungworm highly specific to hedgehogs [23-28], and common in most populations. In a study of 74 dissected hedgehogs in the UK, $71 \%$ were found to be infected with C. striatum [29]. While hedgehogs are the sole definitive hosts for $C$. striatum, the available intermediate host range is much wider. Experimental infections comprising species from several gastropod (slug and snail) families of the orders Stylommatophora and Hygrophila [26,30] suggest a large number of potential hosts in hedgehog environments. Terrestrial molluscs are an integral part of many ecosystems and can be found across a diverse range of habitats throughout the British Isles [31-33].

It is here proposed that a polymerase chain reaction (PCR) based test could be used to rapidly and effectively determine the presence of $C$. striatum in local slug and snail populations, thereby indicating the presence or absence of hedgehogs within a given geographical area. If effective, this test would greatly facilitate monitoring of hedgehog distribution, and could potentially be adapted and developed for use in the monitoring of other species of interest. In the present study, this approach is evaluated by first devising a PCR assay specific for C. striatum, and then comparing results from areas of known hedgehog presence. 


\section{Materials and Methods}

\subsection{Isolation of DNA from Nematodes for Molecular Test Development}

Adult worms of $C$. striatum were collected from the lungs of hedgehogs post mortem, and identified morphologically [29]. Crenosoma vulpis, a closely related species, collected from the lungs of red foxes (Vulpes vulpes) post mortem, was also used. DNA was extracted using the DNeasy Blood and Tissue Kit (Qiagen, Hilden, Germany); according to the manufacturer's instructions, except that adult worms were initially ground in ATL buffer using a microfuge pestle. DNA was eluted in $100 \mu \mathrm{L}$ and stored at $-20{ }^{\circ} \mathrm{C}$ prior to analysis.

\subsection{Primer Design and Multiplex Assay Development}

The second internal transcribed spacer (ITS-2) of ribosomal DNA (rDNA) was chosen as the primary region of interest for primer design, due to its successful use in distinguishing between closely related nematodes in numerous previous studies [34-40]. To obtain sequence information for primer design, primer sequences NC1 and NC2 (Table 1, from Gasser et al. [41] 1993) were used to amplify the ITS-2 region of selected parasite DNA for sequencing. PCR conditions were optimised to achieve a single band of the expected size on an agarose gel. Specific products were purified by mini-column (Qiagen) and sequenced in both directions (Eurofins). Sequences obtained were aligned using the ClustalW function in BioEdit software [42], and a consensus sequence established for each species. Sequences from C. striatum $(n=2)$ and C. vulpis $(n=2)$ were compared with each other and with sequences from Angiostrongylus vasorum (a metastrongylid nematode using gastropod intermediate hosts and common in the study area [43], and Aelustrongylus abstrusus (a metastrongylid feline lungworm also using gastropod intermediate hosts). This was done to find suitable regions for the design of primers that would allow species differentiation by sequence and PCR product size (as illustrated in Supplementary Figure S1). The ITS2 sequences of Crenosoma spp. Were submitted to GenBank with accession numbers MT808322 to MT808325. Primers were designed using Oligo6 (Molecular Biology Insights, Colorado Springs, CO, USA) to uniquely amplify a 157 bp region of C. striatum ITS-2 (C.St), and a 207 bp region of C. vulpis ITS-2 (C.Vu) (Table 1). Primers were checked with NCBI basic local alignment search tool (BLAST) for species specificity. An independent pair of primers for the amplification of a 710-bp fragment of the invertebrate mitochondrial cytochrome $\mathrm{c}$ oxidase subunit I gene (COX1) was selected [44] (henceforth termed COI) as a control to verify that DNA could be amplified from each sample. PCR conditions were optimised for both individual and multiplexed PCRs.

Table 1. The primers and their loci used in PCR tests to identify the presence or absence of Crenosoma striatum in slugs.

\begin{tabular}{cccc}
\hline Primer & Sequence $\left(\mathbf{5}^{\prime} \mathbf{- 3}^{\prime} \mathbf{)}\right.$ & Locus & References \\
\hline NC1 & ACGTCTGGTTCAGGGTTGTT & 5.8S nuclear rRNA gene & {$[41]$} \\
NC2 & TTAGTTTCTTTTCCTCCGCT & 28S nuclear rRNA gene & {$[41]$} \\
C.St-ITS2F & CGATTCCCGTTCTAGTTGAGAC & ITS-2 nuclear rDNA & this study \\
C.St-ITS2R & AAAACCACCTCGACGACATC & ITS-2 nuclear rDNA & this study \\
C.Vu-ITS2F & CGATTCCCGTTTTAGTTAAGGA & ITS-2 nuclear rDNA & this study \\
C.Vu-ITS2R & GCTTATCAATCGTCGAATATCATGC & ITS-2 nuclear rDNA & this study \\
LCO1490 & GGTCAACAAATCATAAAGATATTGG & Mitochondrial cox1 gene & {$[44]$} \\
HC02198 & TAAACTTCAGGGTGACCAAAAAATCA & Mitochondrial cox1 gene & {$[44]$} \\
\hline
\end{tabular}

C.St-ITS2F/R and C.Vu-ITS2F/R = forward and reverse primers for Crenosoma striatum and Crenosoma vulpis.

PCRs were performed in a volume of $15 \mu \mathrm{L}$ including $2 \mu \mathrm{L}$ of template DNA, $2.5 \mathrm{mM} \mathrm{MgCl}$, $0.2 \mathrm{mM}$ dNTPs (Thermo Fisher, Loughborough, UK) $0.025 \mu / \mu \mathrm{L} \mathrm{GoTaq}^{\circledR}$ Flexi polymerase and $1 \times$ buffer (Promega, Southampton, UK) and $1 \times$ primer mix. 10× primer mixes were COI: $10 \mathrm{mM}$ each primer, optimised multiplex $5 \mathrm{mM}$ each C.St primer and $3 \mathrm{mM}$ each C.Vu primer. The PCRs were carried out 
on a Biorad T100 Thermal Cycler using a touchdown profile, consisting of an initial denaturation at $95^{\circ} \mathrm{C}$ for $3 \mathrm{~min}$ followed by nine cycles of $94{ }^{\circ} \mathrm{C}$ for $30 \mathrm{~s}, 65^{\circ} \mathrm{C}\left(1^{\circ} \mathrm{C}\right.$ decrease per cycle) for $20 \mathrm{~s}, 72{ }^{\circ} \mathrm{C}$ extension then 33 cycles of $94{ }^{\circ} \mathrm{C}$ for $30 \mathrm{~s} 55^{\circ} \mathrm{C}$ for $20 \mathrm{~s}$ and $72{ }^{\circ} \mathrm{C}$ extension. Extension at $72{ }^{\circ} \mathrm{C}$ was for $30 \mathrm{~s}$ for the multiplex PCR and $1 \mathrm{~min}$ for the COI PCR. The final extension was $10 \mathrm{~min}$ at $72{ }^{\circ} \mathrm{C}$. PCR products were examined on $1 \%$ agarose gels stained with GelRed ${ }^{\mathrm{TM}}$ (Biotium Inc., Fremont, CA, USA).

The multiplex PCR was initially checked for analytical specificity by testing against a species panel of DNA isolated from morphologically identified adult lungworms, and confirmed to be diagnostic for C.St and C.Vu (see Supplementary Figure S2).

For PCR testing of slug DNA, an initial control COI PCR was performed prior to the test C.St-C.Vu multiplex, and was negative for some samples, mostly from Arion ater slugs, and some appeared tinged with a dark colour. For these, $2 \mu \mathrm{L}$ of genomic DNA was examined on an agarose gel, and the presence of high molecular weight DNA in the extraction was confirmed. Attempts were made to re-purify to negate the effects of inhibitors. For most samples, PCR was successful with the addition of PCRboost ${ }^{\circledR}$ (Biomatrica, San Diego, CA, USA). Multiplex PCRs were carried out under the same conditions for these samples.

PCRs were repeated twice to verify an amplification (test positivity). Test-negative PCRs were scored only if samples with a positive PCR for the control invertebrate COI PCR. The results of the C.St-C.Vu multiplex on positive COI PCR's were analysed using an exact binomial test.

\subsection{Slug Samples}

In order to demonstrate the correlation between $C$. striatum incidence and the presence of hedgehogs, slugs were collected in autumn from Skomer Island, covering an area of approximately 160 ha, and in both spring and autumn in Pennard, covering an area of 0.36 ha: Both areas are in south-west Wales, UK. There are no known reports of hedgehogs (or Foxes) on Skomer Island (personal communication with Mark Hodgson, Wildlife Trust South West Wales), whereas Pennard is an area with an abundant local hedgehog population; more than 180 individuals from this particular region were admitted to Gower Bird Hospital wildlife rehabilitation centre between 2001 and 2017. The slugs collected were identified morphologically by $\mathrm{BR}^{4}$ and then stored at $-20^{\circ} \mathrm{C}$ before processing. The posterior foot section of each slug was removed and macerated prior to tissue lysis.

\subsection{Gastropod DNA Extraction}

Genomic DNAs from 80 slugs were extracted from slug tissue using Dneasy Blood and Tissue Kits (Qiagen, Hilden, Germany) employing a Maxwell ${ }^{\circledR} 16$ MDx Research System (Promega, Maddison, WI, USA) as recommended by the manufacturers. Any undigested tissue and pigment from the larger Arion ater specimens were removed by centrifugation before spin column purification. DNA was eluted in $100 \mu \mathrm{L}$ and stored at $-20^{\circ} \mathrm{C}$ prior to further analysis.

\subsection{Sample Size Calculator}

The number of slugs required to be sampled to provide a reliable indicator of the absence of C. striatum infection, and hence, the absence of hedgehogs, was simulated using the binomial distribution. Thus, the required sample size was defined as that yielding a $<0.05$ probability of zero successes (=detected infections), at a given above-zero true prevalence (p. 64, [45]). This is the sample size needed to avoid a type II error, i.e., falsely declaring the absence of $C$. striatum when actually present, at $p=0.05$.

\section{Results}

Out of the 80 slugs 17 were excluded (Table 2 ), due to negative COI result. Slug samples from Pennard collected in spring $(n=20)$ and autumn $(n=22)$ represented nine species. Overall, the prevalence of $C$. striatum in this sample set was 10\% (95\% exact binomial confidence bounds 3-23\%). Species infected with C. striatum were Arion subfuscus (spring; $n=1$ ), Arion ater agg. (autumn; $n=1$ ) 
and Tandonia sowerbyi (autumn, $n=2$ ). Additionally, the $A$. ater agg. Individual was concurrently infected with $C$. vulpis, confirming the sensitivity of the assay without cross-species amplification. The Skomer slug samples collected in autumn $(n=21)$ comprised two species: A. ater and Lehmannia marginata. Neither $C$. striatum nor $C$. vulpis was detected in any of these samples. Results of the sample size simulation are presented in Figure 1 . At the $10 \%$ prevalence observed in this study, a sample of 29 slugs would be needed to reasonably (at $p=0.05$ ) avoid a false negative, i.e., erroneously conclude that infection is absent. The number of slugs needed would rise at lower prevalence, and fall at higher prevalence.

Table 2. All slug samples included in the proof of principle with their nucleic purity, tissue weight and COI result.

\begin{tabular}{|c|c|c|c|c|c|c|}
\hline & & DNA & $260 / 280$ & Weight & & \\
\hline Sample ID & Slug Species & $\mu \mathrm{g} / \mathrm{mL}$ & Ratio & mg & COI & Excluded \\
\hline \multicolumn{7}{|c|}{ Pennard Spring } \\
\hline 1 & Tandonia sowerbyi & 59.12 & 1.54 & 50 & $+\mathrm{ve}$ & \\
\hline 2 & Tandonia sowerbyi & 86.36 & 1.60 & 34 & $+\mathrm{ve}$ & \\
\hline 3 & Tandonia sowerbyi & 45.64 & 1.60 & 40 & + ve & \\
\hline 4 & Tandonia sowerbyi & 102.74 & 1.83 & 47 & - ve & $x$ \\
\hline 5 & Deroceras panormitanum & 151.01 & 1.91 & 42 & - ve & $x$ \\
\hline 6 & Deroceras panormitanum & 179.24 & 2.00 & 63 & + ve & \\
\hline 7 & Deroceras panormitanum & 180.09 & 1.97 & 55 & - ve & $x$ \\
\hline 8 & Deroceras panormitanum & 94.04 & 1.79 & 48 & $-\mathrm{ve}$ & $x$ \\
\hline 9 & Lehmannia marginata & 7.19 & 1.37 & 50 & + ve & \\
\hline 10 & Lehmannia marginata & 13.98 & 1.42 & 56 & + ve & \\
\hline 11 & Lehmannia marginata & 108.34 & 1.77 & 42 & - ve & $x$ \\
\hline 12 & Lehmannia marginata & 54.50 & 1.89 & 48 & + ve & \\
\hline 13 & Arion hortensis agg. & 30.28 & 1.55 & 45 & $+\mathrm{ve}$ & \\
\hline 14 & Arion hortensis agg. & 37.04 & 1.70 & 41 & + ve & \\
\hline 15 & Arion hortensis agg. & 25.47 & 1.63 & 38 & $+\mathrm{ve}$ & \\
\hline 16 & Arion hortensis agg. & 26.16 & 1.49 & 50 & $-\mathrm{ve}$ & $\mathrm{x}$ \\
\hline SL-1 & Tandonia sowerbyi & 32.00 & 2.05 & 200 & $+\mathrm{ve}$ & \\
\hline SL-2 & Tandonia sowerbyi & 325.69 & 2.03 & 141 & $+\mathrm{ve}$ & \\
\hline SL-3 & Tandonia sowerbyi & 310.11 & 2.04 & & + ve & \\
\hline SL-4 & Arion subfuscus & 464.97 & 2.00 & & + ve & \\
\hline SL-5 & Arion subfuscus & 300.12 & 2.04 & & - ve & $x$ \\
\hline SL-6 & Arion subfuscus & 73.10 & 1.84 & & - ve & $x$ \\
\hline SL-7 & Arion subfuscus & 173.21 & 1.98 & & - ve & $x$ \\
\hline SL-8 & Arion subfuscus & 128.40 & 1.94 & & - ve & $x$ \\
\hline SL-9 & Arion flagellus & 45.35 & 1.89 & & $+\mathrm{ve}$ & \\
\hline SL-10 & Arion flagellus & 226.78 & 2.02 & & +ve & \\
\hline SL-11 & Arion flagellus & 153.25 & 1.90 & & +ve & \\
\hline SL-12 & Arion flagellus & 107.87 & 1.89 & & + ve & \\
\hline SL-13 & Arion flagellus & 107.57 & 1.89 & & $+\mathrm{ve}$ & \\
\hline SL-14 & Arion flagellus & 200.06 & 1.99 & & $+\mathrm{ve}$ & \\
\hline
\end{tabular}


Table 2. Cont

\begin{tabular}{|c|c|c|c|c|c|c|}
\hline & & DNA & $260 / 280$ & Weight & & \\
\hline Sample ID & Slug Species & $\mu \mathrm{g} / \mathrm{mL}$ & Ratio & mg & COI & Excluded \\
\hline \multicolumn{7}{|c|}{ Pennard Autumn } \\
\hline 11.1 & Arion ater agg. & 27.62 & 1.46 & 60 & +ve & \\
\hline 11.2 & Arion ater agg. & 46.00 & 1.81 & 50 & +ve & \\
\hline 11.3 & Arion ater agg. & 23.00 & 1.61 & 50 & +ve & \\
\hline 11.4 & Arion ater agg. & 57.00 & 1.71 & 50 & +ve & \\
\hline 28.1 & Arion ater agg. & 107.77 & 1.70 & 50 & -ve & $\mathrm{x}$ \\
\hline 28.2 & Arion ater agg. & 44.54 & 1.68 & 50 & +ve & \\
\hline 28.3 & Arion ater agg. & 31.04 & 1.41 & 50 & -ve & $x$ \\
\hline 28.4 & Arion ater agg. & 44.49 & 1.61 & 50 & +ve & \\
\hline 15.1 & Arion ater agg. & 32.01 & 1.49 & 50 & +ve & \\
\hline 15.2 & Arion ater agg. & 62.77 & 1.67 & 50 & +ve & \\
\hline 15.3 & Arion ater agg. & 10.13 & 1.12 & 50 & +ve & \\
\hline 15.4 & Arion ater agg. & 61.56 & 1.80 & 80 & +ve & \\
\hline 2.1 & Limax flavus & 0.00 & -0.69 & 50 & -ve & $x$ \\
\hline 2.2 & Limax flavus & 17.91 & 1.26 & 50 & +ve & \\
\hline 2.3 & Limax flavus & 6.27 & 1.12 & 60 & +ve & \\
\hline 2.4 & Limax flavus & 93.23 & 1.77 & 60 & +ve & \\
\hline 1.1 & Tandonia sowerbyi & 76.78 & 0.92 & 58 & +ve & \\
\hline 1.2 & Tandonia sowerbyi & 43.57 & 1.57 & 54 & +ve & \\
\hline 1.3 & Tandonia sowerbyi & 56.92 & 1.70 & 44 & +ve & \\
\hline 1.4 & Tandonia sowerbyi & 40.62 & 1.49 & 47 & +ve & \\
\hline 22.1 & Arion rufus & 2.55 & 0.72 & 58 & +ve & \\
\hline 22.2 & Arion rufus & 0.59 & 0.61 & 48 & -ve & $x$ \\
\hline 22.3 & Arion rufus & 19.40 & 1.21 & 41 & +ve & \\
\hline 22.4 & Arion rufus & 11.28 & 1.06 & 52 & +ve & \\
\hline 23.1 & Arion rufus & 7.08 & 1.08 & 49 & +ve & \\
\hline 23.2 & Arion rufus & 25.60 & 1.34 & 57 & + ve & \\
\hline \multicolumn{7}{|c|}{ Skomer Autumn } \\
\hline SK1 & Arion ater & 179.7 & 1.8 & 30 & +ve & \\
\hline SK2 & Arion ater & 114 & 1.85 & & +ve & \\
\hline SK3 & Arion ater & 53.2 & 1.87 & & +ve & \\
\hline SK4 & Arion ater & 105.1 & 1.83 & & +ve & \\
\hline SK5 & Arion ater & 129.1 & 1.85 & 60 & +ve & \\
\hline SK6 & Arion ater & 172.3 & 1.75 & & +ve & \\
\hline SK7 & Arion ater & 160.3 & 1.64 & 100 & -ve & $x$ \\
\hline SK8 & Arion ater & 271.4 & 1.97 & 20 & -ve & $x$ \\
\hline SK9 & Arion ater & 266.8 & 1.93 & 41 & -ve & $x$ \\
\hline SK10 & Arion ater & 118.8 & 1.86 & & +ve & \\
\hline SK11 & Lehmannia marginata & 107.4 & 1.86 & 48 & +ve & \\
\hline SK12 & Lehmannia marginata & 150.8 & 1.95 & & +ve & \\
\hline SK13 & Lehmannia marginata & 174.7 & 1.93 & 19 & +ve & \\
\hline SK14 & Lehmannia marginata & 166.4 & 2.02 & & +ve & \\
\hline SK15 & Lehmannia marginata & 161.3 & 1.93 & & +ve & \\
\hline SK16 & Lehmannia marginata & 279.7 & 1.95 & & +ve & \\
\hline SK17 & Lehmannia marginata & 355.2 & 1.95 & & +ve & \\
\hline SK18 & Arion ater & 100.1 & 1.91 & & +ve & \\
\hline SK19 & Arion ater & 73.1 & 1.82 & & +ve & \\
\hline SK20 & Arion ater & 97.2 & 1.87 & 83 & +ve & \\
\hline SK21 & Arion ater & 108.7 & 2.1 & & +ve & \\
\hline SK22 & Arion ater & 233.4 & 1.92 & & +ve & \\
\hline SK23 & Arion ater & 130.9 & 1.99 & & +ve & \\
\hline SK24 & Arion ater & 130.6 & 1.9 & & +ve & \\
\hline
\end{tabular}




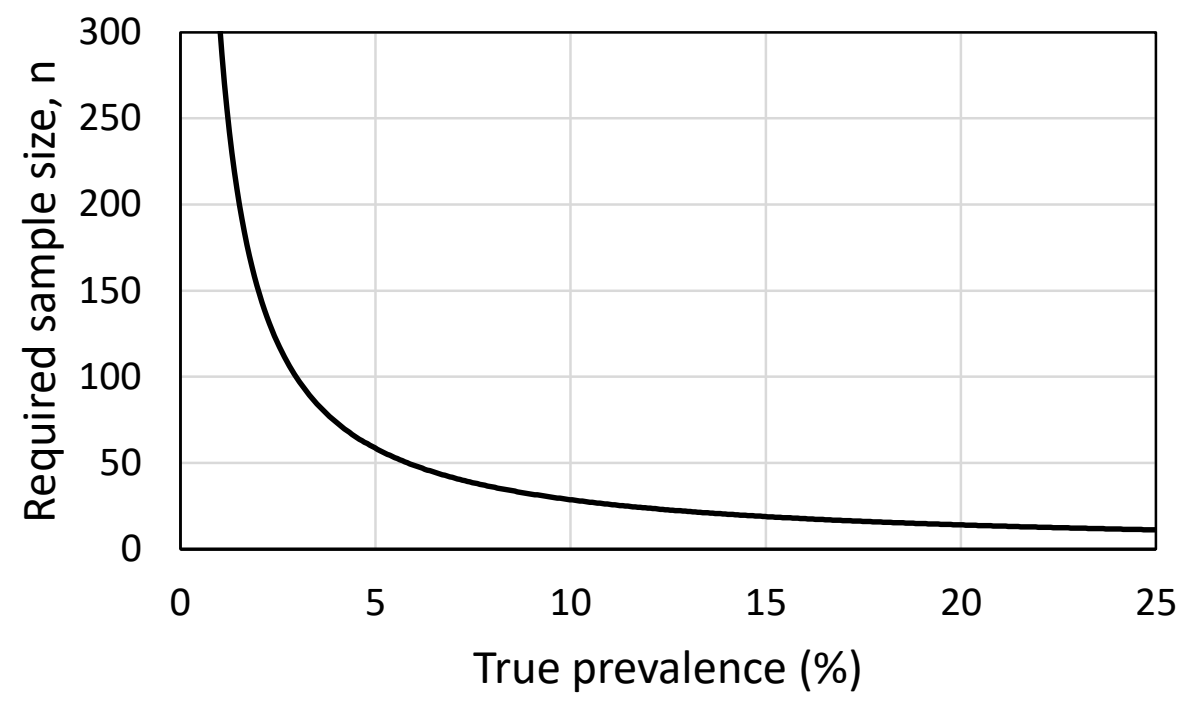

Figure 1. The sample size (=number of slugs) required to detect at least one infected slug, given true prevalence from $1 \%(n=299)$ to $25 \%(n=11)$. Higher prevalence omitted for clarity: $n$ declines further to 5 (at $50 \%$ prevalence) and $3(75 \%)$.

\section{Discussion}

This study demonstrates the use of a multiplex test for Crenosoma species, which can accurately identify and discriminate between closely related species $C$. striatum and C. vulpis from slug tissues. The fact that no $C$. striatum was detected in the Skomer sample set indicates the potential of $C$. striatum as an indicator species for the presence of elusive hedgehogs in any given locale. Furthermore, the sensitivity of the assay suggests that other parasites highly specific to host species of interest could be used in this way for monitoring and surveillance, for instance as part of management programmes for endangered or invasive species [4,46]. Direct detection of environmental DNA also has potential for monitoring of elusive species [47,48]. Detection of host-specific parasites within intermediate hosts, as proposed here, has the advantages of focusing sampling and potentially longer persistence of DNA in the form of living immature parasite stages.

The methodology described here may need refinement in terms of sample preparation. Some parasites have a preferred site within their host; for instance, Angiostrongylus vasorum occupies the right ventricle and pulmonary arteries in its vertebrate hosts [49], whilst $C$. striatum prefers the bronchioles and bronchi of the lungs [26]. The affinity of these parasites to particular sites within the host may extend to the intermediate host, such that sub-sampling of tissue could bias results and affect method sensitivity. Further research needs to be carried out to determine if $C$. striatum has a predilection site in slugs, to increase the efficacy of detection in slug tissue.

To increase the chances of detecting a parasitised slug, species that have been active the longest, and therefore, had the greatest opportunity to acquire parasite infections should, in principle, be targeted for sampling. For example, A. subfuscus activity has been seen to peak between May and June with little between-year deviation [50], making it an ideal candidate for spring and summer sampling. The present study found $A$. subfuscus to be the only species with a positive $C$. striatum result in spring sampling. Similarly, A. ater and T. sowerbyi would be of major interest in autumn and winter sampling, with their peak activity being in January or between August and October, respectively [50]. Arion ater may be of particular interest in future research, as it was the only species that presented simultaneous infection with both C. striatum and C. vulpis. Additionally, the detection of C. striatum in A. ater, A. subfuscus and T. sowerbyi appears to be the first confirmed report of infection in these species [30]. This suggests that the potential intermediate host range of $C$. striatum could be much greater than previously thought. Extensions to the present study could further develop the test for hedgehog monitoring through targeting particular slug species and anatomical sites, and by matching the target 
sample size to the expected prevalence and required precision. The number and cost of PCR assays performed per geographical site could also be reduced by pooling samples from different slugs. These refinements require validation and could establish whether parasite abundance in slugs is related to hedgehog population density, which if it were found to be the case, would enhance its utility as a monitoring tool. Regardless of this relationship, however, results here suggest that presence or absence of C. striatum correlates, as expected, with that of its hedgehog definitive host, and can, therefore, be used as a robust indirect indicator of hedgehog presence. The required number of slugs to be sampled in order to reasonably exclude the possibility of $C$. striatum depends on the underlying prevalence, which is unlikely to be known in a newly surveyed site. Further information on the range of prevalence of $C$. striatum infection in gastropods in areas inhabited by hedgehogs would, therefore, be useful to evaluate the feasibility and efficiency of the present approach across the species range.

The approach presented here could be extended to other systems, where highly host-specific parasites are present at reasonably high prevalence, distinguishable from closely related species, and accessible, for example in easily sampled intermediate hosts. The most fundamental of these factors is the host specificity. Host specificity is often under or over-estimated for parasitic species [51], and parasite-host interactions are rarely well-understood in wild animals [52]. Most parasites can infect multiple host species [53-55], albeit to a highly varied extent [56], rendering most as unsuitable for host population studies. Helminths, however, often demonstrate high host-specificity, with nearly $50 \%$ of those reported in one study of primates inhabiting a single host species [54]. The sensitivity of the assay presented herein demonstrates that quick and accurate delineation between closely related parasite species can be achieved. It is entirely possible that this methodology could be adapted to other vertebrate species of conservation concern, wherever a suitable parasite species can be identified. To date, only a small number of parasites with singular definitive hosts have been described; Table 3 provides examples of such species. It may be the case that host-specific helminths occur commonly; however, further research is needed in order to clarify this. Furthermore, taxonomic revision frequently leads to a reassessment of host specificity: For example, many nematodes found in amphibia had been previously identified as Rhabdias rana, molecular analysis later demonstrated historical misidentification [57], and new species were described as a result. Therefore, it is quite possible that many parasitic species identified before the modern molecular biology era, may have been incorrectly described, increasing the possibility of detecting species-specific and molecularly distinct parasites with potential as indicators of host presence. In addition to taxonomy, ecological factors determine the realisation of potential host range, and are changing in many systems [58]. Shifts in prevalence and host range might have to be taken into account during parasite-based monitoring programmes, and at the same time can provide additional information on host ecology and infection patterns.

Further improvements could be made through development as a loop-mediated isothermal amplification (LAMP-PCR), using similar methodology to that previously described $[59,60]$. This has potential for a test which could be used in a field setting: Feng et al. [59] found the LAMP-PCR method had lower, but adequate sensitivity for the specific detection of cestode DNA as compared to multiplex PCR, while Abbasi et al. [60] demonstrated 10-fold increased sensitivity over PCR for the detection of Schistosoma spp. in infected snails. 
Table 3. Examples of helminth species that to date, have only been identified in a singular definitive host.

\begin{tabular}{|c|c|c|c|c|c|}
\hline Parasite Group & Helminth Species & Definitive Host & Common Name & Host Class & Reference \\
\hline \multicolumn{6}{|l|}{ Nematode } \\
\hline & Abbreviata perenticola & Varanus giganteus & Perentie & Reptilia & [61] \\
\hline & Abbreviata physignathi & Physignathus lesueurii & Australian Water Dragon & Reptilia & [61] \\
\hline & Abbreviata glebopalmae & Varanus glebopalma & Black Palmed Rock Monitor & Reptilia & [61] \\
\hline & Abbreviata barrowi & Pseudechis australis & Mulga Snake & Reptilia & [61] \\
\hline & Nematodirus davtiani alpinus * & Capra ibex & Alpine Ibex & Mammalia & [62] \\
\hline & Filaroides martes & Martes americana & American Pine Marten & Mammalia & {$[63]$} \\
\hline & Perostrongylus falciformis & Meles meles & European badger & Mammalia & {$[64]$} \\
\hline & Crenosoma striatum * & Erinaceus europaeus & European Hedgehog & Mammalia & \\
\hline & Rhabdias bakeri & Rana sylvatica & Wood Frog & Amphibia & [57] \\
\hline & Rhabdias ambystomae & Ambystoma maculatum & Spotted Salamander & Amphibia & {$[65]$} \\
\hline & Parachordatortilis mathevossianae & Falco tinnunculus & Common Kestrel & Aves & [66] \\
\hline & Physaloptera apivori & Pernis apivorus & European Honey Buzzard & Aves & [66] \\
\hline & Physaloptera Mexicana * & Buteo buteo & Common Buzzard & Aves & [66] \\
\hline & Serratospiculum tendo & Falco peregrinus & Peregrine falcon & Aves & [66] \\
\hline \multicolumn{6}{|l|}{ Trematode } \\
\hline & Urotrema scabridum * & Anolis sagrei & Brown Anole & Reptilia & [67] \\
\hline & Pleurogonius malaclemys & Malaclemys terrapin & Diamondback Terrapin & Reptilia & [22] \\
\hline & Mesocoelium lanfrediae & Rhinella marina & Cane Toad & Amphibia & [68] \\
\hline & Parastrigea intermedia & Circus aeruginosus & Western Marsh Harrier & Aves & [66] \\
\hline \multicolumn{6}{|l|}{ Cestode } \\
\hline & Schistotaenia tenuicirrus & Podiceps grisegena & Red Necked Grebe & Aves & [69] \\
\hline & Cladotaenia foxi & Falco Peregrinus & Peregrine falcon & Aves & [66] \\
\hline
\end{tabular}

* denotes parasite species for which the definitive host is geographically isolated from other host species. 


\section{Conclusions}

We conclude that proof of principle has been demonstrated in using terrestrial parasite DNA to confirm the presence of hedgehogs in a given locale. PCR tests can be used to effectively detect and delineate isolates of C. striatum and C. vulpis from gastropod samples. A critical assessment of different slug tissue and nematode extraction methods, and epidemiological factors, is necessary for the improvement and development of the method described here. This method could provide significant support for monitoring and conservation efforts in hedgehogs, and could pave the way for similar methods to be employed for monitoring of other terrestrial species whose conservation is of concern.

Supplementary Materials: The following are available online at http://www.mdpi.com/2076-2615/10/8/1420/s1, Figure S1: Sequence alignment of ITS-2 sequences showing positions of discriminatory primers resulting in specific PCR products differing in length by $50 \mathrm{bp}$. Figure S2: PCR of extracted nematode DNA with CS/CV multiplexed primer set illustrating specific amplification.

Author Contributions: Conceptualization, S.A.; Formal analysis, C.G., M.W. and E.R.M.; Funding acquisition, S.A., D.F. and E.R.M.; Investigation, S.A., C.G. and B.R.; Methodology, S.A., C.G., R.B.G., A.J. and E.R.M.; Resources, C.G., D.F., R.B.G., A.J., S.M. and E.R.M.; Supervision, C.G. and E.R.M.; Writing-original draft, S.A., C.G., M.W. and E.R.M.; Writing-review \& editing, B.R., D.F., R.B.G., A.J., S.M., M.W. and E.R.M. All authors have read and agreed to the published version of the manuscript.

Funding: Joint funded by a grant from the People's Trust for Endangered Species, the British Hedgehog Preservation Society, the Gower Society and the Welsh Institute for Sustainable Environments.

Acknowledgments: We would like to thank the Gower Society, the People's Trust for Endangered Species, the British Hedgehog Preservation Society and the Welsh Institute for Sustainable Environments for financial support. We would also like to thank the Wildlife Trust of South and West Wales for their help and hospitality on Skomer Island.

Conflicts of Interest: The authors declare no conflict of interest.

\section{Abbreviations}

$\begin{array}{ll}\text { rDNA } & \text { ribosomal deoxyribonucleic acid } \\ \text { PCR } & \text { Polymerase chain reaction } \\ \text { dNTPs } & \text { deoxyribonucleotide triphosphate } \\ \text { mM } & \text { millimolar } \\ \text { bp } & \text { base pair } \\ \text { agg } & \text { aggregate } \\ \text { ha } & \text { hectare }\end{array}$

\section{References}

1. Thompson, W.L. Sampling Rare or Elusive Species: Concepts, Designs and Techniques for Estimating Population Parameters; Island Press: Washington, DC, USA, 2004.

2. Kendall, K.C.; Metzgar, L.H.; Patterson, D.A.; Steele, B.M. Power of Sign Surveys To Monitor Population Trends. Ecol. Appl. 1992, 2, 422-430. [CrossRef]

3. Linnell, J.D.C.; Swenson, J.E.; Kvam, T.; Nikus, N.; Fagrapport, N.; Oppdragsmelding, N. Methods for Monitoring European Large Carnivores-A Worldwide Review of Relevant Experience; Institutt Norsk for Naturforskning: Trondheim, Norway, 1998; Volume 549, ISBN 8242609519.

4. Eggert, L.S.; Eggert, J.A.; Woodruff, D.S. Estimating population sizes for elusive animals: The forest elephants of Kakum National Park, Ghana. Mol. Ecol. 2003, 12, 1389-1402. [CrossRef] [PubMed]

5. Amori, G. Erinaceus Europaeus The IUCN Red List of Threatened Species 2016: E.T29650A2791303; IUCN: Gland, Switzerland, 2016. [CrossRef]

6. Holsbeek, L.; Rodts, J.; Muyldermans, S. Hedgehog and other animal traffic victims in Belgium: Results of a countrywide survey. Lutra 1999, 42, 111-119.

7. Huijser, M.P.; Bergers, P.J.M. The effect of roads and traffic on hedgehog (Erinaceus europaeus) populations. Biol. Conserv. 2000, 95, 111-116. [CrossRef]

8. Macdonald, D.; Burnham, D. The State of Britains Mammals_People's Trust for Endangered Species; The Wildlife Conservation Research Unit, Oxford: London, UK, 2011. 
9. Roos, S.; Johnston, A.; Noble, D. UK Hedgehog Datasets and Their Potential for Long-Term Monitoring; British Trust for Ornithology: Setford, UK, 2012; pp. 1-63.

10. Krange, M. Change in the Occurrence of the West European Hedgehog (Erinaceus Europaeus) in Western Sweden during 1950-2010. Ph.D. Thesis, Karlstad University, Karlstad, Sweden, 2015.

11. Hof, A.R.; Bright, P.W. Quantifying the long-term decline of the West European hedgehog in England by subsampling citizen-science datasets. Eur. J. Wildl. Res. 2016, 62, 407-413. [CrossRef]

12. Wembridge, D. The State of Britain's Hedgehogs 2011; British Hedgehog Preservation Society \& Peoples Trust for Endangered Species: Ludlow, UK, 2011.

13. Cavallini, P. Faeces count as an index of fox abundance. Acta 1994, 39, 417-424. [CrossRef]

14. Silveira, L.; Jácomo, A.T.A.; Diniz-Filho, J.A.F. Camera trap, line transect census and track surveys: A comparative evaluation. Biol. Conserv. 2003, 114, 351-355. [CrossRef]

15. McKelvey, K.S.; Kienast, J.V.; Aubry, K.B.; Koehler, G.M.; Maletzke, B.T.; Squires, J.R.; Linduist, E.L.; Loch, S.; Schwartz, M.K. DNA Analysis of Hair and Scat Collected Along Snow Tracks to Document the Presence of Canada Lynx. Wildl. Soc. Bull. 2006, 34, 451-455. [CrossRef]

16. Yarnell, R.W.; Pacheco, M.; Williams, B.; Neumann, J.L.; Rymer, D.J.; Baker, P.J. Using occupancy analysis to validate the use of footprint tunnels as a method for monitoring the hedgehog Erinaceus europaeus. Mammal Rev. 2014, 44, 234-238. [CrossRef]

17. McKelvey, K.S.; Aubry, K.B.; Schwartz, M.K. Using Anecdotal Occurrence Data for Rare or Elusive Species: The Illusion of Reality and a Call for Evidentiary Standards. Bioscience 2008, 58, 549. [CrossRef]

18. Dogiel, V.; Bychowsky, B. Parasites of fisheries of the Caspian Sea. Tr. Kompleks. Izucheniyu Kaspiiskogo Morya $1939,7,150$.

19. Herrington, W.C.; Bearse, H.; Firth, F.E. Observations on the life history, occurence, and distribution of the redfish parasite Sphyrion lumpium. U. S. Bur. Fish. Spec. Rep. 1939, 5, 1-18.

20. MacKenzie, K. Parasites as indicators of host populations. Int. J. Parasitol. 1987, 17, 345-352. [CrossRef]

21. Williams, H.H.; MacKenzie, K.; McCarthy, A.M. Parasites as biological indicators of the population biology, migrations, diet, and phylogenetics of fish. Rev. Fish Biol. Fish. 1992, 2, 144-176. [CrossRef]

22. Byers, J.E.; Altman, I.; Grosse, A.M.; Huspeni, T.C.; Maerz, J.C. Using parasitic trematode larvae to quantify an elusive vertebrate host. Conserv. Biol. 2011, 25, 85-93. [CrossRef]

23. Skrjabin, K.I.; Petrow, A.M. A description of the genus Crenosoma Molin, 1861 (Metastrongylidae, Nematota). Parasitology 1928, 20, 329-335. [CrossRef]

24. Dougherty, E.C. A review of the genus Crenosoma Molin, 1861 (Nematoda: Trichostrongylidae); its history, taxonomy, adult morphology, and distribution. J. Helminthol. Soc. Wash. 1945, 12, 44-62.

25. Lammler, G.; Saupe, E. Infection experiments with the lungworm of the hedgehog, Crenosoma striatum. Z. Parasitenkd. 1968, 31, 87-100.

26. Barus, V.; Blazek, K. The life cycle and the pathogenicity of the nematode Crenosoma-striatum. Folia Parasitol. 1971, 18, 215-226.

27. Reeve, N. Hedgehogs; T. \& A.D. Poyser: London, UK, 1994; ISBN1 085661081X. ISBN2 9780856610813.

28. Mirzaei, M. Infection with Crenosoma striatum lungworm in Long-eared Hedgehog (Hemiechinus auritus) in Kerman province southeast of Iran. Turk. J. Parasitol. 2015, 38, 255-257. [CrossRef]

29. Gaglio, G.; Allen, S.; Bowden, L.; Bryant, M.; Morgan, E. Parasites of European hedgehogs (Erinaceus europaeus) in Britain: Epidemiological study and coprological test evaluation. Eur. J. Wildl. Res. 2010, 56, 839-844. [CrossRef]

30. Grewal, P.S.; Grewal, S.K.; Tan, L.; Adams, B.J. Parasitism of molluscs by nematodes: Types of associations and evolutionary trends. J. Nematol. 2003, 35, 146-156. [PubMed]

31. Mason, C.F. Snail populations, beech litter production, and role of snails in litter decomposition. Oecologia 1970, 5, 213-239. [CrossRef] [PubMed]

32. South, A. Terrestrial Slugs, Biology, Ecology and Control; Chapman and Hall: London, UK, 1992; ISBN 0-412-36810-2.

33. Kennedy, C.R. Ecology of the Acanthocephala; Cambridge University Press: Cambridge, UK, 2006; ISBN 9780521850087.

34. Chilton, N.B.; Gasser, R.B.; Beveridge, I. Differences in a ribosomal DNA sequence of morphologically indistinguishable species within the Hypodontus macropi complex (Nematoda: Strongyloidea). Int. J. Parasitol. 1995, 25, 647-651. [CrossRef] 
35. Félix, M.A.; Braendle, C.; Cutter, A.D. A streamlined system for species diagnosis in caenorhabditis (Nematoda: Rhabditidae) with name designations for 15 distinct biological species. PLoS ONE 2014, 9, e0118327. [CrossRef]

36. Gasser, R.B.; Monti, J.R. Identification of parasitic nematodes by PCR-SSCP of ITS-2 rDNA. Mol. Cell. Probes 1997, 11, 201-209. [CrossRef]

37. Sinclair, R.; Melville, L.; Sargison, F.; Kenyon, F.; Nussey, D.; Watt, K.; Sargison, N. Gastrointestinal nematode species diversity in Soay sheep kept in a natural environment without active parasite control. Vet. Parasitol. 2016, 227, 1-7. [CrossRef]

38. Wimmer, B.; Craig, B.H.; Pilkington, J.G.; Pemberton, J.M. Non-invasive assessment of parasitic nematode species diversity in wild Soay sheep using molecular markers. Int. J. Parasitol. 2004, 34, 625-631. [CrossRef]

39. Gasser, R.B. PCR-based technology in veterinary parasitology. Vet. Parasitol. 1999, 84, 229-258. [CrossRef]

40. Gasser, R.B. Molecular tools-Advances, opportunities and prospects. Vet. Parasitol. 2006, 136, 69-89. [CrossRef]

41. Gasser, R.B.; Chilton, N.B.; Hoste, H.; Beveridge, I. Rapid sequencing of rDNA from single worms and eggs of parasitic helminths. Nucleic Acids Res. 1993, 21, 2525-2526. [CrossRef] [PubMed]

42. Hall, T.A. BioEdit: A user-friendly biological sequence alignment editor and analysis program for Windows 95/98/NT. Nucleic Acids Symp. Ser. 1999, 45, 95-98.

43. Aziz, N.A.A.; Daly, E.; Allen, S.; Rowson, B.; Greig, C.; Forman, D.; Morgan, E.R. Distribution of Angiostrongylus vasorum and its gastropod intermediate hosts along the rural-urban gradient in two cities in the United Kingdom, using real time PCR. Parasit. Vectors 2016, 9, 56. [CrossRef] [PubMed]

44. Folmer, O.; Black, M.; Hoeh, W.; Lutz, R.; Vrijenhoek, R. DNA primers for amplification of mitochondrial cytochrome c oxidase subunit I from diverse metazoan invertebrates. Mol. Mar. Biol. Biotechnol. 1994, 3, 294-299. [PubMed]

45. Hilborn, R.; Mangel, M. The Ecological Detective: Confronting models with data. In The Ecological Detective; Princeton University Press: Princeton, NJ, USA, 1997; p. 315. ISBN 978-0691034966.

46. Piaggio, A.J.; Engeman, R.M.; Hopken, M.W.; Humphrey, J.S.; Keacher, K.L.; Bruce, W.E.; Avery, M.L. Detecting an elusive invasive species: A diagnostic PCR to detect Burmese python in Florida waters and an assessment of persistence of environmental DNA. Mol. Ecol. Resour. 2014, 14, 374-380. [CrossRef]

47. Mills, L.S.; Citta, J.J.; Lair, K.P.; Schwartz, M.K.; Tallmon, D.A. Estimating Animal Abundance Using Noninvasive DNA Sampling: Promise and Pitfalls. Ecol. Appl. 2000, 10, 283-294. [CrossRef]

48. Jones, R.A.; Brophy, P.M.; Davis, C.N.; Davies, T.E.; Emberson, H.; Stevens, P.R.; Williams, H.W. Detection of Galba truncatula, Fasciola hepatica and Calicophoron daubneyi environmental DNA within water sources on pasture land, a future tool for fluke control? Parasit. Vectors 2018, 11, 1-9. [CrossRef]

49. Morgan, E.R.; Shaw, S.E.; Brennan, S.F.; De Waal, T.D.; Jones, B.R.; Mulcahy, G. Angiostrongylus vasorum: A real heartbreaker. Trends Parasitol. 2005, 21, 49-51. [CrossRef]

50. Barnes, H.F.; Weil, J.W. Slugs in Gardens: Their Numbers, Activities and Distribution. Part 1. J. Anim. Ecol. 1944, 13, 140-175. [CrossRef]

51. Poulin, R.; Keeney, D.B. Host specificity under molecular and experimental scrutiny. Trends Parasitol. 2007. [CrossRef]

52. Desdevises, Y.; Morand, S.; Legendre, P. Evolution and determinants of host specificity in the genus Lamellodiscus ( Monogenea ). Biol. J. Linn. Soc. 2002, 77, 431-443. [CrossRef]

53. Cleaveland, S.; Laurenson, M.K.; Taylor, L.H. Diseases of humans and their domestic mammals: Pathogen characteristics, host range and the risk of emergence. Philos. Trans. R. Soc. Lond. 2001, 356, 991-999. [CrossRef] [PubMed]

54. Pedersen, A.B.; Altizer, S.; Poss, M.; Cunningham, A.A.; Nunn, C.L. Patterns of host specificity and transmission among parasites of wild primates. Int. J. Parasitol. 2005, 35, 647-657. [CrossRef] [PubMed]

55. Woolhouse, M.E.J.; Taylor, L.H.; Haydon, D.T. Population Biology of Multihost Pathogens. Science 2001, 1828, 1-5. [CrossRef] [PubMed]

56. Poulin, R.; Krasnov, B.R.; Mouillot, D. Host specificity in phylogenetic and geographic space. Trends Parasitol. 2011, 27, 355-361. [CrossRef]

57. Tkach, V.V.; Kuzmin, Y.; Pulis, E.E. A New Species of Rhabdias From Lungs of the Wood Frog, Rana Sylvatica, in North America: The Last Sibling of Rhabdias Ranae? J. Parasitol. 2006, 92, 631-636. [CrossRef] 
58. Cable, J.; Barber, I.; Boag, B.; Ellison, A.R.; Morgan, E.R.; Murray, K.; Pascoe, E.L.; Sait, S.M.; Wilson, A.J.; Booth, M. Global change, parasite transmission and disease control: Lessons from ecology. Philos. Trans. R. Soc. B Biol. Sci. 2017, 372. [CrossRef]

59. Feng, K.; Li, W.; Guo, Z.; Duo, H.; Fu, Y.; Shen, X.; Tie, C.; Rijie, E.; Changqin, X.; Luo, Y.; et al. Development of LAMP assays for the molecular detection of taeniid infection in canine in Tibetan rural area. J. Vet. Med. Sci. 2017, 79, 1986-1993. [CrossRef]

60. Abbasi, I.; King, C.H.; Muchiri, E.M.; Hamburger, J. Detection of Schistosoma mansoni and Schistosoma haematobium DNA by loop-mediated isothermal amplification: Identification of infected snails from early prepatency. Am. J. Trop. Med. Hyg. 2010, 83, 427-432. [CrossRef]

61. Jones, H.I. Physalopterine nematodes in Australian reptiles: Interactions and patterns of infection. Aust. J. Zool. 2014, 62, 180-194. [CrossRef]

62. Zaffaroni, E.; Manfredi, M.T.; Citterio, C.; Sala, M.; Piccolo, G.; Lanfranchi, P. Host specificity of abomasal nematodes in free ranging alpine ruminants. Vet. Parasitol. 2000, 90, 221-230. [CrossRef]

63. Seville, R.S.; Addison, E.M. Nongastrointestinal helminths in marten (Martes americana) from Ontario, Canada. J. Wildl. Dis. 1995, 31, 529-533. [CrossRef] [PubMed]

64. Deak, G.; Mihalca, A.D.; Hirzmann, J.; Colella, V.; Alexandru, F.; Cavalera, M.A.; Gheorghe, F.; Bauer, C.; Monica, A.; Ali, A.; et al. Validity of genus Perostrongylus Schlegel, 1934 with new data on Perostrongylus falciformis (Schlegel, 1933) in European badgers, Meles meles (Linnaeus, 1758): Distribution, life-cycle and pathology. Parasite Vector 2018, 56, 1-16. [CrossRef] [PubMed]

65. Kuzmin, Y.; Tkach, V.V.; Snyder, S.D. Rhabdias ambystomae sp. n. (Nematoda: Rhabdiasidae) from the north American spotted salamander Ambystoma maculatum (Amphibia: Ambystomatidae). Comp. Parasitol. 2001, 68, 228-235.

66. Santoro, M.; Kinsella, J.M.; Galiero, G.; degli Uberti, B.; Aznar, F.J. Helminth Community Structure in Birds of Prey (Accipitriformes and Falconiformes) in Southern Italy. J. Parasitol. 2012, 98, 22-29. [CrossRef]

67. Bundy, D.A.P.; Harris, E.A. Helminth parasites of jamaican anoles (Reptilia: Iguanidae): A comparison of the helminth fauna of 6 anolis species. J. Helminthol. 1987, 61, 77-83. [CrossRef]

68. Gomes, T.F.F.; Melo, F.T.V.; Giese, E.G.; Furtado, A.P.; Gonçalves, E.C.; Santos, J.N. A new species of Mesocoelium (Digenea: Mesocoeliidae) found in Rhinella marina (Amphibia: Bufonidae) from Brazilian Amazonia. Mem. Inst. Oswaldo Cruz 2013, 108, 186-191. [CrossRef]

69. Stock, T.M.; Holmes, J.C. Host specificity and exchange of intestinal helminths among four species of grebes (Podicipedidae). Can. J. Zool. 1987, 65, 669-676. [CrossRef] 